\title{
Effects of ionizing radiation of seeds on the initial growth of barley, determination of the frequency and spectrum of mutational variability in $M_{1}$ morphological properties
}

\author{
Laura Tokhetova, Bibigul Baizhanova*, Raushan Nurymova, Danabek Nurzhanov, Nurali Nurgaliev \\ Korkyt Ata Kyzyl-Orda State University, 120014, Kyzylorda, Aitekebie str. 29A, Republic of Kazakhstan
}

*Corresponding author: bibi64@inbox.ru

\begin{abstract}
Gamma irradiation technology is considered to be very promising for trait-based plant modification. The effect of $\gamma$-irradiation on the germination, growth, and productivity of daughter generations of barley $\mathrm{M}_{1}$ and $\mathrm{M}_{2}$ is highly relevant. The aims of the study was the creation of a source material for barley breeding in the form of mutant lines with selectively valuable traits, by treating seeds with ionizing radiation using an electron accelerator of the Park of Nuclear Technologies JSC (Kurchatov, Republic of Kazakhstan); as well as to improve and expand the classical methods of breeding based on induced mutagenesis in creating an original gene pool of the source and breeding material of barley for the accelerated and effective introduction of stress tolerant(to salinization and drought) varieties into production in the conditions of Aral Sea impacted landscapes. Seeds of the two varieties of barley were treated with five doses of radiation (from $50 \mathrm{~Gy}$ to $250 \mathrm{~Gy}$ ). The germination and various morphological characteristics of their seedlings at different growing phases were compared with the non-irradiated (control) treatment. The results of this preliminary study showed that both treated varieties were sensitive to the $\gamma$-irradiation and showed suppressed morphological properties, where the highest dose of $250 \mathrm{~Gy}$ showed most inhibiting effect resulting in death of barely seedling. The results obtained will be applied for the further expanded research with other specified doses of $\gamma$ ray treatment of seeds in order to create a basis in strengthening and deploying full-scale breeding work for diversified crop production in the region and improving existing varieties for further breeding.
\end{abstract}

Keywords: $\gamma$-radiation, breeding, barley, mutant lines.

\section{Introduction}

Producing sufficient and quality food for a growing population is one of the major challenges facing the food and agriculture sector. This is especially challenging given the context of an ever-changing, changing climate. Given the many challenges facing agricultural food systems, new technologies and techniques need to be developed and adapted to grow high-yielding crop varieties that can withstand multiple environmental stresses during the growing season (Gerard et al., 2020).

The Kyzylorda region of the central Kazakhstan is located in extremely unfavourable conditions for the implementation of crop production, where intensive desertification, salinization and soil deflation are observed (Hu et al., 2020; Verón et al., 2006; Reynolds et al., 2007). Long-term cultivation of rice in Kyzylorda region led to a general rise in the level of groundwater, which resulted in salinization of arable soils by $60 \%$ over past 10 years (Baimbetovand Sagimbayev, 2005). Lack of moisture, high temperatures, drought, dry wind, and return of cold temperatures, salinization, and a decrease in the level of fertility of the arable soil layer are the main limiting factors of the 
studied Aral Sea region. Because the most effective and economical way to reduce their negative impacts on cultural vegetation is genetic breeding approach, researches on the creation of new resistant varieties of barley adapted to local environmental conditions specified with high salinization and droughts are very relevant.

Radiation breeding allows obtaining mutant lines that outstand in resistance to abiotic stress factors, as well as significantly reducing the time for breeding new varieties by direct propagation of mutant lines with a complex of positive traits. In the last decade, the mutational methods of creating varieties developed by the International Atomic Energy Agency of Austria was widely accepted in the Asian and Latin American regions and has achieved very good results. Examples include the highprotein bare-grain mutant barley variety Molina-5, cultivated in the highlands of the Andes. The world achievements of induced mutagenesis in the context of cultivated crops clearly indicate the role of the genotype in the mutation process: crops are classified into high- and low-stable. Rye, oats, and durum wheat are regarded as low stable; while barley, rice and soft wheat are highly stable (Dobrovolsky and Kubarev, 2009; Marcu et al 2013; Majeed and Muhammad 2010; Liu et al., 2019; Shiyu et al., 2020; Wang et al., 2019; Thomas, 2020). As world experience shows, the possibilities of experimental mutagenesis in its simple, classical, execution have already been largely exhausted, therefore, the search for new mutagenic factors and methods of their action for the identification of utilitarian genotypes is constantly being researched. In this regard, at present, an urgent need has arisen to obtain the original gene pool of the initial and breeding material of the most important agricultural crops using new mutational methods, for the rapid and effective creation of new varieties.In addition, in recent years, many countries are interested in the peaceful use of atomic energy; in particular, the processing of agricultural products with ionizing radiation is the most modern method that meets the needs of today's agricultural market. Thus, the use of atomic energy in agriculture solves the problems of breeding and pest control, preservation the crop yield and increases its storage time, improve the quality of seed and increase productivity (IAEA 2019; Jo and Kim 2019). Generally it is considered that irradiation of seeds of grain cereals with low doses of gammarays leads to increased protein content and higher carbohydrate and vitamin levels (Jan et al., 2012). However, there are almost no studies on seed pre-treatment with higher doses of gamma radiation on germination and early growth characteristics of barley. Taking into consideration the potential of gamma irradiation technology on the trait based modification of plants the influence of $\gamma$-irradiations on germination, growth and yield in $\mathrm{M}_{1}$ and $\mathrm{M}_{2}$ filial generations (Rawat et al., 2019) of barley is highly relevant.

At present, in the breeding work of the Aral Sea scientists, the only classical method for creating such varieties is intra-species hybridization based on the "pedigree". Therefore, the main prerequisite for these studies was the expansion of breeding methods in the creation of a fundamentally new starting material based on induced mutagenesis, which makes it possible to obtain 
mutant lines characterized by resistance to abiotic stress factors, such as salt-tolerant. In addition $\gamma$ radiation of seeds supposedly will significantly shorten the time spent for breeding process by direct propagation of mutant lines with a complex of positive traits.

The goals of this study were:

- To study the effectiveness of ionizing radiation on approved and promising varieties of barley,

- To study the methodology of mutagenic effects on plant growth,

- To obtain promising mutants of barley as a starting material for breeding varieties for the conditions of the Aral Sea region in Kazakhstan.

Implementation of this project is expected to create a solid scientific basis in strengthening and deploying full-scale breeding work for diversified crops in this region and improving existing varieties of local breeding. We expect that the results of this study will find wide application in theoretical and practical breeding of barley, which will reveal the genetic nature of complex polygenic traits and enhance the efficiency of genetics and breeding projects in Kazakhstan, in general.

\section{Materials and methods}

The objects of research were two barley varieties (Syr Aruy and Inkar) that are constant in terms of commercially valuable traits and biological properties. The seeds of the barley varieties were treated with ionizing radiation using the ILU-10 electron accelerators at the Park of Nuclear Technologies JSC (Kurchatov) in the following parameters of the radiation processing technological process:

- electron energy - $5 \mathrm{MeV}$;

- average current of the electron beam - 0.04; 0.08; 0.12;0.16;0.20 mA;

- speed of the beam section of the conveyor - $9 \mathrm{~m} / \mathrm{min}$;

- the range of absorbed doses was $50 \pm 10 \%$ Gy (Gray); $100 \pm 10 \%$ Gy; $200 \pm 10 \%$ Gy and $250 \pm$ $10 \%$ Gy.

The treatment of seeds with ionizing radiation was carried out using the ILU-10 electron accelerator of the Park of Nuclear Technologies Joint Stock Company (Kurchatov, East Kazakhstan region).

In the laboratory conditions, the optimal radiation doses were selected by careful analysis of growth parameters at the initial stage of barley growth and development by determining the following characteristics: germination energy, laboratory germination of seeds, measuring the length of roots and shoots of 10 and 15-days-old seedlings and other auxiliary indicators (Udovenko 1968; Methodological guidelines 1989). Unirradiated seeds served as control.

Field experiments were carried out in April (2019) according to the generally accepted scheme: treated and control seeds were sown manually on plots with an area: in the first year of the experiment (2019)- at least $1.0 \mathrm{~m}^{2}$ along the track of the marker, in subsequent year (2020) with an increase in the area of plots depending on the number of seeds obtained. The phenological observations of the growth 
and development of plants, the beginning and end of the onset of phases (not shown in this paper), counts, and selection of plants for biometric analysis were carried out according to the methods described by Udovenko (1968), Dospekhov (1973) and Methodological guidelines (1981).

Determination of the frequency of visible dominant mutations on plants was carried out by means of an individual assessment of plants to identify the effect of mutagens (leaf color, plant height, ear shape, the presence of anthocyan coloration of awns, leaf ears, wax bloom, graininess and other morphological traits) by visually viewing the plants from each treatment in comparison with the control. Harvesting was carried out manually with a preliminary selection of 10 plants for structural analysis, and the remaining plants were harvested by family groups, with the main spike (ears) separately from the lateral.

The initial stage of the research included studying the effect of various doses of ionizing radiation on the growth and development of barley plants in the early stages (germination energy, laboratory germination, height, length, mass of shoots and roots of 10 and 15 days old seedlings) in order to determine the test indicator of the most effective mutagenic exposure to radiation treatment.

The second stage of the research included studies on the effect of ionizing radiation on the commercial and biological characteristics of barley, such as field germination, plant condition (preservation for harvest), the length of growing period, the onset of the heading phase, elements of productivity, grain weight per unit area and the spectrum of modified forms in $\mathbf{M}_{1}$. Figure 1. shows one representative experimental plots as a sample.

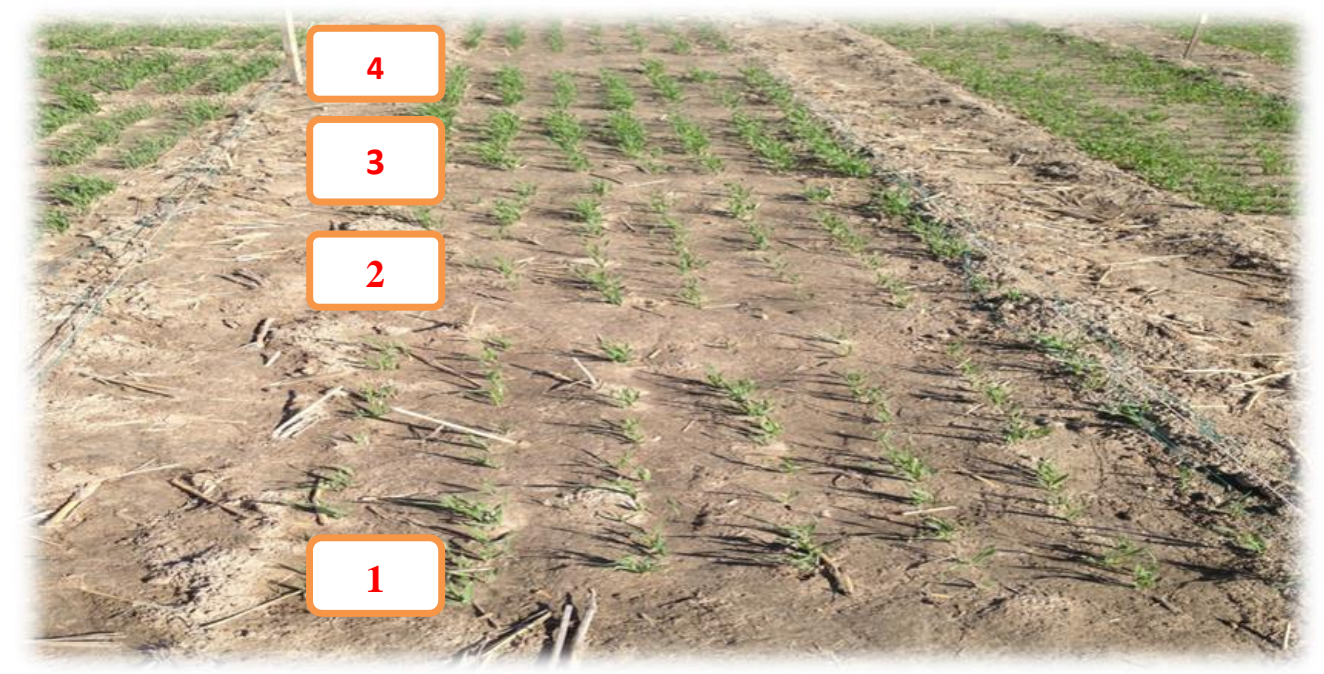

Figure 1. Differentinitial stages of barley varieties on 02.04.2019. Treatment no 3(radiation $150 \pm 10 \%$ Gy): 1 Inkar; 2-Syr Aruy; 3-controlInkar; 4-controlSyrAruy

Typically mutation frequencies in the $M_{1}$ generation are estimated from those of the $M_{2}$ or $M_{3}$ generations, assuming a Mendelian segregation of mutant alleles (Naito et al., 2005). Themorphological parameters of the two studied varieties of barley were statistically processed 
according to Kostyloeva and Kostylev (2017). The data obtained was processed in Excel and Statistica 19 software, and the mean differences were calculated by Duncan's multiple range test.

\section{Results and Discussions}

The effect of radiation treatment of seeds of the Syr Aruy variety on germination energy and seed germination was insignificant (except for the first seed treatment) and their indicators in all doses were at the same level. Interestingly, at a minimum radiation dose of $50 \mathrm{~Gy}$, a significant decrease in germination was observed (85.4\%), while in other treatments with increased doses. This indicator was at the control level in the range of 94.4-96.9\% (Table 1).A different picture was observed for the Inkar barley variety, in which the laboratory germination decreased with increasing doses of ionizing radiation to $75.2 \%$ (Table 2). The differences in comparison with the control were statistically significant. The study of the effect of ionizing radiation on the length of 10 and 15-daysold seedlings showed that as the absorbed doses increase, a slight decrease in the length of 10-days-old seedlings to 12.6 and $12.9 \mathrm{~cm}$, respectively, was observed for the varieties of Syr Aruy and Inkar, compared to 14.4 and $13.8 \mathrm{~cm}$ in the control treatments. A similar picture was observed for the weight of 15-daysold seedlings and roots, where at the highest irradiation dose of $250 \mathrm{~Gy}$ the seedling lengths were 14.9 and 14.5 versus 18.3 and 17.2 in the control treatment (Tables 1 and 2).

We found that at a dose of $200 \pm 10 \%$ Gy there was a better morphological characteristics of seedlings of both varieties, in comparison with other treatments (though not statistically significant), but still less efficient than in the control (Table 1 and Table 2). This phenomenon cannot be explained at these preliminary stages of the experiments. However, it deserves more detailed molecular and genetic studies in a perspective. Many studies reported that low radiation doses of pre-sowing seed treatment accelerate the passage of the first phases of growth and reduce the growing season. Each phase of plant growth is characterized by a unique physiology where any change in growth pattern ultimately affects maturity and yield (Jan et al 2012). Low doses of irradiation is considered to stimulate specific plant morphological parameters and increase plant yield (Yu et al.2007; Melki and Dahmani 2009) through so called hormesis phenomenon (Korystov and Narimanov 1997), by changing the hormonal signalling network in plant cells or by increasing the antioxidative capacity of cells (Kim et al., 1998; Wi et al., 2005). 
Table 1. Analysis of the seed germination and seedlings characteristics of the Syr Aruy barley variety at different doses of seed radiation treatment

\begin{tabular}{|c|c|c|c|c|c|c|c|c|}
\hline \multirow{2}{*}{$\begin{array}{l}\text { No of } \\
\text { treatment }\end{array}$} & \multirow{2}{*}{$\begin{array}{l}\text { Range of absorbed } \\
\text { doses, Gy }\end{array}$} & \multirow{2}{*}{$\begin{array}{l}\text { Number of germinated } \\
\text { seeds, pcs (after } 4 \text { days) }\end{array}$} & \multirow{2}{*}{$\begin{array}{c}\text { Laboratory } \\
\text { germination, \% }\end{array}$} & \multirow{2}{*}{$\begin{array}{l}\text { Length of 10-days-old } \\
\text { sprouts, cm }\end{array}$} & \multicolumn{4}{|c|}{ Characteristics of 15-days-old seedlings } \\
\hline & & & & & $\begin{array}{l}\text { Seedling } \\
\text { length, } \mathrm{cm}\end{array}$ & $\begin{array}{l}\text { Seedling } \\
\text { weight, g }\end{array}$ & $\begin{array}{l}\text { Root length, } \\
\mathrm{cm}\end{array}$ & Root weight, g \\
\hline 1 & $50 \pm 10 \%$ & $42.7 \mathrm{a} *$ & $85.4 a \pm 0.98$ & $14.4 \mathrm{a} \pm 0.21$ & $17.1 \mathrm{a} \pm 0.56$ & $0.165 \mathrm{a} \pm 0.004$ & $5.12 \mathrm{a} \pm 0.08$ & $0.087 \mathrm{a} \pm 0.021$ \\
\hline 2 & $100 \pm 10 \%$ & $47.3 \mathrm{~b}$ & $95.6 \mathrm{~b} \pm 0.56$ & $14.2 \mathrm{a} \pm 0.46$ & $17.4 \mathrm{a} \pm 0.53$ & $0.171 \mathrm{~b} \pm 0.009$ & $7.07 \mathrm{~b} \pm 0.15$ & $0.123 b \pm 0.015$ \\
\hline 3 & $150 \pm 10 \%$ & $46.7 \mathrm{~b}$ & $94.4 \mathrm{~b} \pm 0.89$ & $13.0 \mathrm{~b} \pm 0.32$ & $16.3 \mathrm{~b} \pm 0.91$ & $0.152 \mathrm{c} \pm 0.012$ & $7.92 \mathrm{~b} \pm 0.21$ & $0.112 \mathrm{~b} \pm 0.011$ \\
\hline 4 & $200 \pm 10 \%$ & $46.3 b$ & $96.9 b \pm 0.57$ & $14.5 \mathrm{a} \pm 0.51$ & $17.8 \mathrm{a} \pm 0.89$ & $0.167 a \pm 0.003$ & $7.96 \mathrm{~b} \pm 0.27$ & $0.128 \mathrm{~b} \pm 0.018$ \\
\hline 5 & $250 \pm 10 \%$ & $45.8 \mathrm{c}$ & $94.6 \mathrm{~b} \pm 0.92$ & $12.6 \mathrm{~b} \pm 0.95$ & $14.9 \mathrm{c} \pm 1.86$ & $0.157 c \pm 0.016$ & $6.31 \mathrm{c} \pm 0.31$ & $0.117 \mathrm{~b} \pm 0.021$ \\
\hline 6 & $\begin{array}{l}\text { Control (not } \\
\text { irradiated) }\end{array}$ & 48.3d & $96.6 b \pm 0.98$ & $14.4 a \pm 0.85$ & $18.3 \mathrm{~d} \pm 0.97$ & $0.173 b \pm 0.006$ & $8.55 d \pm 0.05$ & $0.139 \mathrm{c} \pm 0.004$ \\
\hline
\end{tabular}

*Different letters indicate statistically significant differences at $\mathrm{p}<0.05$; according to Duncan's multiple range test

Table 2. Analysis of the seed germination and seedlings characteristics of the Inkar barley variety at different doses of seed radiation treatment

\begin{tabular}{|c|c|c|c|c|c|c|c|c|}
\hline \multirow[b]{2}{*}{$\begin{array}{c}\text { No of } \\
\text { treatment }\end{array}$} & \multirow[b]{2}{*}{$\begin{array}{l}\text { Range of absorbed } \\
\text { doses, Gy }\end{array}$} & \multirow[b]{2}{*}{$\begin{array}{c}\text { Number of germinated } \\
\text { seeds, pcs (after } 4 \text { days) }\end{array}$} & \multirow[b]{2}{*}{$\begin{array}{c}\text { Laboratory } \\
\text { germination, \% }\end{array}$} & \multirow{2}{*}{$\begin{array}{l}\text { Length of 10-days-old } \\
\text { sprouts, } \mathrm{cm}\end{array}$} & \multicolumn{4}{|c|}{ Characteristics of 15-day-old seedlings } \\
\hline & & & & & $\begin{array}{l}\text { Seedling } \\
\text { length, } \mathrm{cm}\end{array}$ & $\begin{array}{l}\text { Seedling weight, } \\
\mathrm{g}\end{array}$ & $\begin{array}{l}\text { Root length, } \\
\mathrm{cm}\end{array}$ & Root weight, $\mathrm{g}$ \\
\hline 1 & $50 \pm 10 \%$ & $42.2 \mathrm{a}^{*}$ & $84.4 \mathrm{a} \pm 0.87$ & $13.5 \mathrm{a} \pm 0.51$ & $16.5 \mathrm{a} \pm 0.15$ & $0.152 \mathrm{a} \pm 0.009$ & $6.15 \mathrm{a} \pm 0.12$ & $0.119 \mathrm{a} \pm 0.012$ \\
\hline 2 & $100 \pm 10 \%$ & $40.3 b$ & $80.6 \mathrm{~b} \pm 0.34$ & $13.3 \mathrm{a} \pm 0.44$ & $15.2 b \pm 0.24$ & $0.148 \mathrm{a} \pm 0.012$ & $6.22 \mathrm{a} \pm 0.18$ & $0.129 \mathrm{~b} \pm 0.002$ \\
\hline 3 & $150 \pm 10 \%$ & $40.8 \mathrm{~b}$ & $81.6 b \pm 0.29$ & $13.0 \mathrm{a} \pm 0.52$ & $14.8 \mathrm{~b} \pm 0.32$ & $0.144 \mathrm{ab} \pm 0.015$ & $6.57 \mathrm{a} \pm 0.04$ & $0.127 \mathrm{~b} \pm 0.004$ \\
\hline 4 & $200 \pm 10 \%$ & $39.8 b$ & $89.6 c \pm 0.48$ & $14.0 \mathrm{~b} \pm 0.61$ & $16.0 \mathrm{a} \pm 0.27$ & $0.145 \mathrm{ab} \pm 0.012$ & $7.52 b \pm 0.16$ & $0.135 \mathrm{~b} \pm 0.009$ \\
\hline 5 & $250 \pm 10 \%$ & $37.6 \mathrm{c}$ & $75.2 \mathrm{~d} \pm 0.31$ & $12.9 \mathrm{c} \pm 0.91$ & $14.5 \mathrm{~b} \pm 0.31$ & $0.140 \mathrm{~b} \pm 0.019$ & $5.15 \mathrm{c} \pm 0.09$ & $0.108 \mathrm{c} \pm 0.018$ \\
\hline 6 & $\begin{array}{l}\text { Control (not } \\
\text { irradiated) }\end{array}$ & 48.7d & $97.4 \mathrm{e} \pm 0.23$ & $13.8 \mathrm{a} \pm 0.34$ & $17.2 c \pm 0.29$ & $0.157 \mathbf{a} \pm \mathbf{0 . 0 0 3}$ & $9.27 \mathrm{~d} \pm 0.04$ & $0.151 d \pm 0.009$ \\
\hline
\end{tabular}

* Different letters indicate statistically significant differences at $p<0.005$; according to Duncan's multiple range test 
This phenomenon is triggered by a general adaptive response of the organism to stress (Mattson and Calabrese, 2010) Duration and a dose of radiation affect the directions and changes in plant morphological generative parameters either by enhancement or inhibition of them (Kim et al., 1998; Wi et al., 2005).

Many studies have been carried out to evidence the effects of different doses of $\gamma$-irradiation on growth and yield attributes (Jan et al., 2012; Rawat et al., 2019; Kazakova et al., 2020; Volkova et al., 2020). In our study the inhibition of growth induced by high-dose irradiation is probably attributed to the cell cycle arrest during somatic cell division and/or varying damage to the entire genome (Preuss and Britt, 2003; Jan et al., 2012). In the study of Jan et al. (2012) the relationship between growth of irradiated plants and the dose of $\gamma$-irradiation has been manifested by investigating the morphological changes and seedling growth of irradiated plants, where low doses inhibited auxin synthesis while larger doses can destroyed auxin activity directly.

Thus, the analysis of the growth processes of barley plants showed that the selected radiation doses did not have a lethal effect on the barley seeds. However, during the early stages of barley growth, the radiation dose $250 \pm 10 \%$ Gy resulted in a significant inhibition of the development of the sprout and roots, and subsequently to death of the seedling (Table 3). The death of seedlings at this dose of irradiation was the highest and amounted to $65-70 \%$ (Table 3). The data obtained indicate that the maximum permissible dose of irradiation of barley was the dose with an average electron beam current of $0.2 \mathrm{~mA}$ and250 Gy.

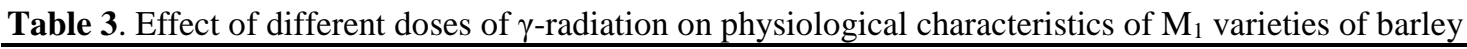

\begin{tabular}{|c|c|c|c|c|c|}
\hline No & $\begin{array}{l}\text { Range of absorbed } \\
\text { doses, Gy }\end{array}$ & $\begin{array}{c}\text { Plant } \\
\text { preservation, \% }\end{array}$ & $\begin{array}{c}\text { Preservation of } \\
\text { plants for } \\
\text { harvesting, } \%\end{array}$ & $\begin{array}{l}\text { "Sowing-heading" } \\
\text { period, days }\end{array}$ & $\begin{array}{c}\text { Vegetation period, } \\
\text { days }\end{array}$ \\
\hline \multicolumn{6}{|c|}{ Syr Aruy variety } \\
\hline & Original variety-control & 69.3 & 81.7 & 36 & 75 \\
\hline 1 & $50 \pm 10 \%$ & 50.0 & 80.0 & 40 & 79 \\
\hline 2 & $100 \pm 10 \%$ & 44.4 & 81.7 & 40 & 79 \\
\hline 3 & $150 \pm 10 \%$ & 41.6 & 80.8 & 40 & 79 \\
\hline 4 & $200 \pm 10 \%$ & 42.8 & 80.0 & 44 & 82 \\
\hline \multirow[t]{2}{*}{5} & $250 \pm 10 \%$ & 30.5 & 79.5 & 49 & 84 \\
\hline & $\mathrm{LSD}_{05}$ & 0.14 & 0.52 & 0.17 & 1.14 \\
\hline \multicolumn{6}{|c|}{ Inkar variety } \\
\hline & Original variety-control & 67.6 & 88.7 & 40 & 79 \\
\hline 1 & $50 \pm 10 \%$ & 44.8 & 86.9 & 44 & 82 \\
\hline 2 & $100 \pm 10 \%$ & 32.2 & 84.5 & 42 & 82 \\
\hline 3 & $150 \pm 10 \%$ & 31.4 & 83.1 & 44 & 82 \\
\hline 4 & $200 \pm 10 \%$ & 33.8 & 82.7 & 47 & 84 \\
\hline \multirow[t]{2}{*}{5} & $250 \pm 10 \%$ & 25.2 & 79.6 & 49 & 86 \\
\hline & $\mathrm{LSD}_{05}$ & 0.25 & 0.76 & 0.15 & 1.01 \\
\hline
\end{tabular}

The studied varieties showed differences in laboratory seed germination depending on the dose of the mutagen, which indicates that the effect of ionizing radiation depends on the genetic nature of the varieties. The laboratory studies revealed a significant decrease in root length and mass values with increasing radiation doses in comparison with the control, which indicates significant differences 
between the experimental treatments. Therefore, these signs can serve as one of the informative (test) indicators when assessing effective doses of ionizing radiation.

In the $\mathrm{M}_{1}$ plants of Syr Aruy variety, the variation in field germination in the treatments of mutagenic exposure ranged from $38.0 \%(250 \pm 10 \%)$ to $50.0 \%(50 \pm 10 \%)$; while for the control plants it was $69.3 \%$. In the $\mathrm{M}_{1}$ plants of Inkar variety, the field germination rate varied from $33.6 \%$ $(150 \pm 10 \%)$ to $44.8 \%(50 \pm 10 \%)$.

As can be seen from Figure 2, the value of field germination in both varieties varied proportionally to the radiation doses, namely, a decrease in germination values was observed with an increase in the treatment dose. A preliminary conclusion can be made that a more significant effect on this trait was exerted not by the genotype, but by the dose of the mutagen in accordance with earlier cited researches in this paper.

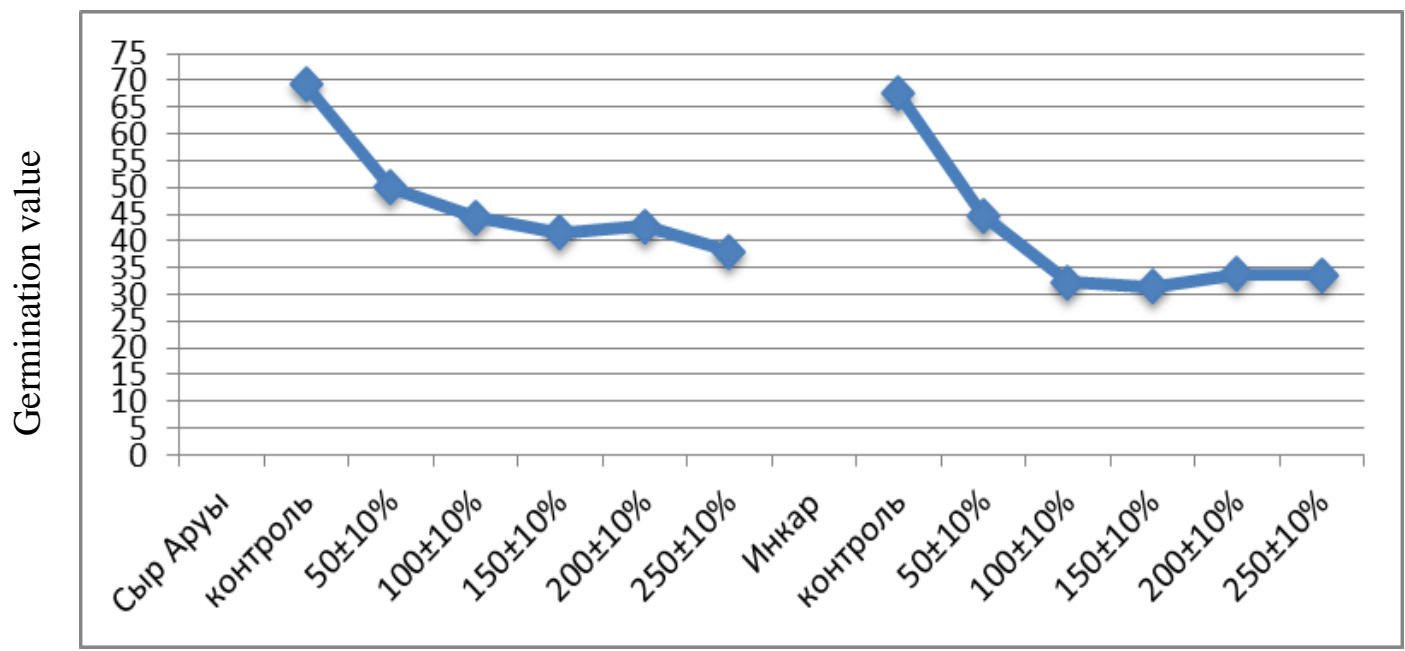

Figure 2. Changes in the field germination $(\%)$ of barley varieties at different doses of radiation (Gy)

It was observed that various doses of ionizing radiation had a stimulating effect on the productive tillering and the weight of 1000 grains, but somewhat reduced the grain number in the ear (Table 4). Productive tillering in both varieties increased with an increase in the radiation dose to 3.3and 3.8 pieces per plant at 250 Gy for Syr Aruy variety and Inkar variety, respectively. Although ionizing radiation had a stimulating effect on the increase of productive tillering, it also caused unfulfilled spikes in the lateral shoots and their under ripening (Table 5). In general, a decrease in the productivity of barley varieties under the influence of various doses of ionizing radiation was caused, first of all, by low field germination, due to inhibition of growth processes already in the phase of germination of the grain or their non-viability. 
Table 4. Effect of different doses of $\gamma$-radiation on productivity of $\mathrm{M}_{1}$ plants of barley

\begin{tabular}{|c|c|c|c|c|c|c|}
\hline No & $\begin{array}{l}\text { Range of absorbed } \\
\text { doses, Gy }\end{array}$ & $\begin{array}{c}\text { Productive tillering, } \\
\text { pcs/plant }\end{array}$ & $\begin{array}{c}\text { Number of } \\
\text { grains per } \\
\text { ear, pcs }\end{array}$ & $\begin{array}{l}\text { Weight of } 1000 \\
\text { grains, } g\end{array}$ & $\begin{array}{l}\text { Grain weight } \\
\text { per ear, } g / \mathrm{m}^{2}\end{array}$ & $\begin{array}{l}\text { Deviation from } \\
\text { control, } \mathrm{g} / \mathrm{m}^{2}\end{array}$ \\
\hline \multicolumn{7}{|c|}{ Syr Aruy variety } \\
\hline & $\begin{array}{l}\text { Original vaiety- } \\
\text { control }\end{array}$ & $1.7 \pm 0.04$ & $24.7 \pm 0.92$ & 45.0 & 504.9 & 0.0 \\
\hline 1 & $50 \pm 10 \%$ & $2.1 \pm 0.03$ & $21.1 \pm 0.53$ & 45.8 & 379.9 & -125.0 \\
\hline 2 & $100 \pm 10 \%$ & $2.4 \pm 0.02$ & $20.0 \pm 0.23$ & 45.4 & 357.5 & -147.4 \\
\hline 3 & $150 \pm 10 \%$ & $2.8 \pm 0.03$ & $19.8 \pm 0.08$ & 46.0 & 337.3 & -167.6 \\
\hline 4 & $200 \pm 10 \%$ & $2.8 \pm 0.05$ & $19.2 \pm 0.25$ & 45.2 & 336.8 & -168.1 \\
\hline 5 & $250 \pm 10 \%$ & $3.3 \pm 0.06$ & $16.5 \pm 0.87$ & 46.0 & 318.1 & -186.8 \\
\hline \multicolumn{7}{|c|}{ Inkar variety } \\
\hline & $\begin{array}{l}\text { Original variety- } \\
\text { control }\end{array}$ & $1.8 \pm 0.03$ & $25.2 \pm 0.86$ & 45.4 & 514.9 & 0.0 \\
\hline 1 & $50 \pm 10 \%$ & $2.3 \pm 0.03$ & $20.1 \pm 0.68$ & 46.7 & 291.6 & -223.3 \\
\hline 2 & $100 \pm 10 \%$ & $3.5 \pm 0.04$ & $16.0 \pm 0.74$ & 47.9 & 268.7 & -246.2 \\
\hline 3 & $150 \pm 10 \%$ & $3.5 \pm 0.05$ & $21.0 \pm 0.38$ & 45.2 & 257.1 & -257.8 \\
\hline 4 & $200 \pm 10 \%$ & $3.8 \pm 0.04$ & $21.2 \pm 0.57$ & 45.9 & 254.2 & -260.7 \\
\hline 5 & $250 \pm 10 \%$ & $3.4 \pm 0.05$ & $16.7 \pm 0.14$ & 47.1 & 231.8 & -283.1 \\
\hline
\end{tabular}

Throughout the growing season, the selection of modified plants by characteristics differing from the original control variety was carried out by visual comparative method. In the current year (2020), in the $M_{1}$ modified forms were detected for the density and shape of the spike, awns, plant height, spike branching and others (Figure 3; Table 5).
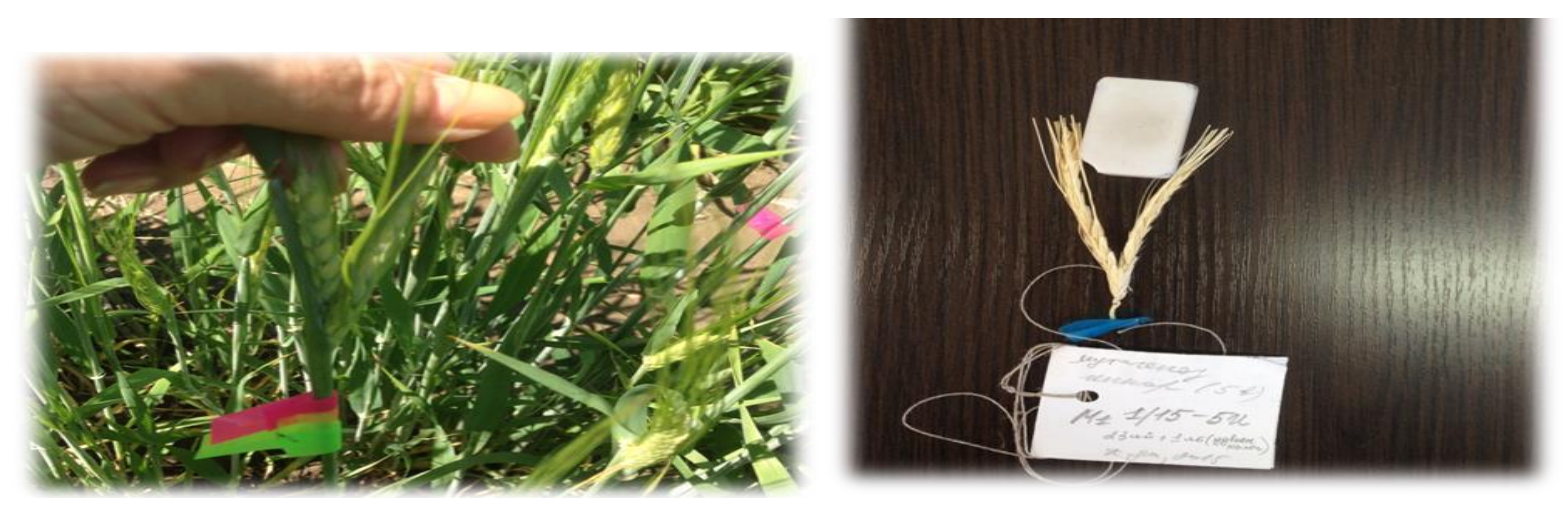

Figure 3. Ear modification - branching: barley variety Inkar, treatment No. 5 - $250 \pm 10 \%$ Gy

The first two years of the study showed that most of the studied morphological parameters of barley were suppressed by irradiation of seeds, regardless of the dose, compared with the control (unirradiated seeds). Generally, the higher the dose, the more negative changes were found. The detected modified forms were marked with flags and removed separately (Figure 4a, 4b, 4c, 4d). Further, under laboratory conditions, the selection of ears with visible morphological changes was repeated (Figure 5). Each selected ear will be sown next year in a $1^{\text {st }}$ year breeding nursery using a square-nesting method (hole/ear), 36 lines in total. The rest of the plants in the context of each treatment were manually threshed, cleaned and prepared for sowing in a hybrid nursery. The area of the plots $\mathrm{M}_{2}$ according to the treatments and depending on the number of seeds will be from 10 to $22 \mathrm{~m}^{2}$. 
Table 5. Modified forms in $M_{1}$ in barley varieties treated by ionizing radiation

\begin{tabular}{|c|c|c|c|c|c|c|c|c|c|c|c|}
\hline \multirow[b]{2}{*}{$\begin{array}{c}\text { No of } \\
\text { treatm } \\
\text { ent }\end{array}$} & \multirow[b]{2}{*}{$\begin{array}{c}\text { Range of } \\
\text { absorbed doses, } \\
\text { Gy }\end{array}$} & \multirow[b]{2}{*}{ 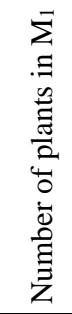 } & \multirow[b]{2}{*}{ 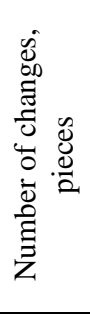 } & \multicolumn{8}{|c|}{ Morphological changes, number of cases } \\
\hline & & & & $\begin{array}{l}\vec{E} \\
\frac{000}{0} \\
\overrightarrow{1}\end{array}$ & 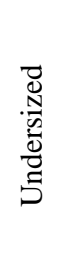 & $\begin{array}{l}\text { च̈ } \\
0 \\
0 \\
0 \\
0 \\
0\end{array}$ & 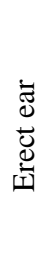 & 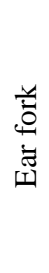 & 紊 & 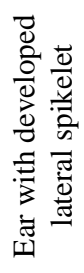 & 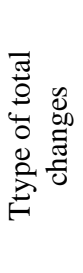 \\
\hline & \multicolumn{11}{|c|}{ Syr Aruy } \\
\hline 1 & $50 \pm 10 \%$ & 250 & 2 & - & 1 & - & - & - & - & 1 & 2 \\
\hline 2 & $100 \pm 10 \%$ & 222 & 7 & - & - & - & 4 & - & 1 & 2 & 3 \\
\hline 3 & $150 \pm 10 \%$ & 208 & 5 & 1 & - & 2 & 1 & - & - & 1 & 4 \\
\hline 4 & $200 \pm 10 \%$ & 214 & 6 & 2 & - & 1 & 2 & - & 1 & - & 4 \\
\hline \multirow[t]{2}{*}{5} & $250 \pm 10 \%$ & 190 & 24 & 5 & 3 & 4 & 8 & 1 & - & 2 & 6 \\
\hline & \multicolumn{11}{|c|}{ Inkar } \\
\hline 1 & $50 \pm 10 \%$ & 224 & 3 & - & - & 2 & - & - & 1 & - & 2 \\
\hline 2 & $100 \pm 10 \%$ & 161 & 4 & - & - & - & 3 & - & 1 & - & 2 \\
\hline 3 & $150 \pm 10 \%$ & 157 & 6 & 2 & - & 2 & - & - & - & 2 & 3 \\
\hline 4 & $200 \pm 10 \%$ & 169 & 8 & 3 & - & 2 & 2 & - & - & 1 & 4 \\
\hline 5 & $250 \pm 10 \%$ & 168 & 23 & 12 & - & 3 & 2 & 1 & 1 & 4 & 6 \\
\hline
\end{tabular}

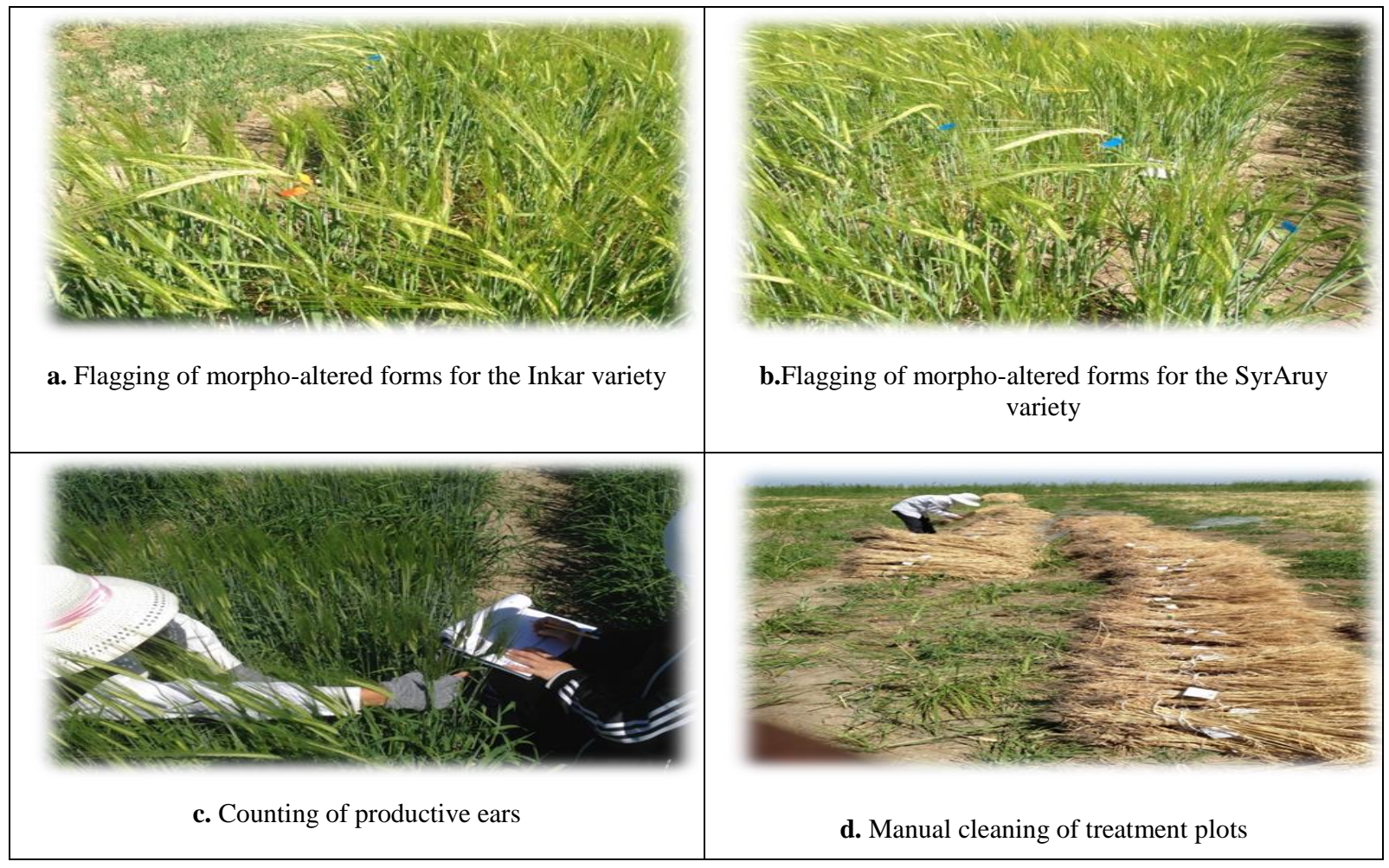

Figure 4. Stages of the field works on two barley varieties 


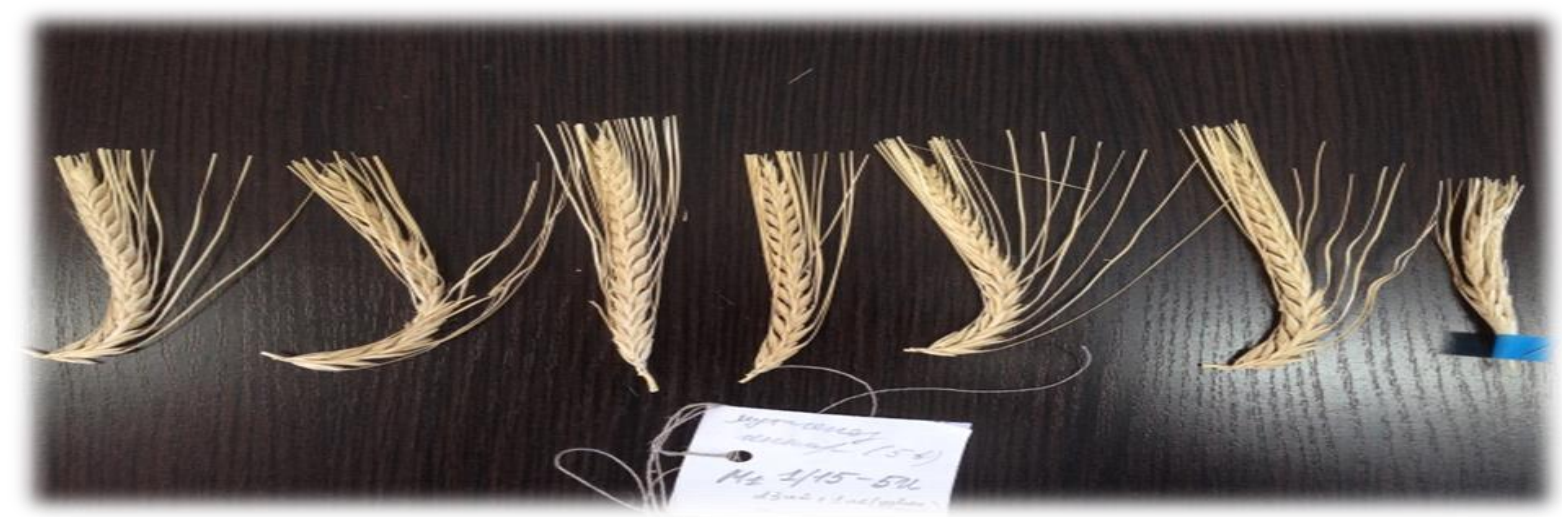

Figure 5. Selection of modified forms in laboratory conditions

During the experiment the preservation of plants for harvest in $\mathrm{M}_{1}$ plants did not significantly differ from the indicators of the control treatment and the doses of radiation applied didn't have an inhibitory effect on plant preservation (Table 3).But during the plant growth, mutagens had a stimulating effect on the duration of individual growth phases, in particular on the "sowing to heading" period (Table 3).Thus, the duration of the sowing-heading period varied from 40 to 49 days for the Syr Aruy variety and from 42 to 49 days for Inkar. The latest onset of the heading phase was noted in the treatment with a high radiation dose of $250 \pm 10 \%$, in which the deviation from the control variant was 13 and 9 days for Syr Aruy and Inkar, respectively. Accordingly, this was reflected in the final indicator of ontogeny - the length of growing season. In the early season variety Syr Aruy with a growing season of no more than 75 days, the length of growing season prolonged in proportion to the increase in the radiation dose from 4 to 9 days. A similar situation was observed for the mid-season Inkar variety. It was revealed that the Inkar variety, in comparison with the Syr Aruy, significantly reduces productivity under the influence of mutagens, which indicates a significant share of the contribution of the genotype itself, i.e. dependence of the effect of a mutagen on the genetic nature of the genotype.

There are different results and conclusion on the effect of seed radiation on germination rate and pattern reported by various similar studies worldwide. For example, Kazakova et al. (2020) and Volkova et al. (2020) found no significant differences between 0 and 20Gy treatments in pretreatment of barley seeds, while the length and weights of 100 Gy-treated roots and shoots were significantly lower than in the control. In our study all doses, including the least dose of radiation (50 Gy) showed statistically significant difference compared with the control. Similarly, to our results Kumari and Singh (1996) observed inhibited germination of the seeds treated with higher doses. Zimmermann et al. (1996) and Thapa (2004) found that low doses of radiation of seeds stimulate faster germination and growth of roots and leaves. Kuzin et al. (1975) found that at low doses of irradiation (40Gy) this is might be due to activation of RNA synthesis. The inhibition of germination at high doses of the barley seed radiation is most probably associated with histological and cytological 
changes; disruption and disorganisation of the tunica or seed layer that is directly proportional to the intensity of exposure to $r$-rays as well as impaired mitosis or virtual elimination of cell division in the meristematic zones during germination (Lokesha et al., 1992). In our study high doses of $\gamma$-radiation obviously imposed an inhibitory distress effect (Volkova et al., 2020) on germination, growth and development of barley.

\section{Conclusions}

Generally, the morphological and growth properties of studied barley varieties were inhibited by irradiation with $\gamma$-ray seed pre-treatment where the higher dose resulted in greater inhibition of each phases of barley growth and development. The highest dose of $250 \mathrm{~Gy}$ showed most negative effects leading to the death of barley seedlings. The phenological phases were prolonged for the both early and mid-season studied varieties.The results of this preliminary experiment on the use of induced mutagenesis as a source for the creation of new initial forms will be applied to an expanded research with application of other ranges of $\gamma$-ray seed pre-treatment to find outan optimal range of irradiation and most suitable mutant lines. Taking into consideration that low-dose gamma irradiation has high potential positive effect on barley morphological, germination and yield characteristics and also tolerance to stresses, the further deeper studies of changes and behavior in molecular and genetic levels are perspectives. The aim of further research is to uncover the possibilities of synthetic breeding, to obtain mutant lines resistant to salt and drought stress, as well as to significantly reduce the time required for selection of new varieties by direct propagation of mutant lines with a complex of positive traits.

\section{References}

Baimbetov K., Sagimbayev S. 2005. Agromeliorative monitoring of irrigated lands and prospects for rice planting in the Aral sea region. Bulletin of agricultural science of Kazakhstan 4:1214.https://nauka.kz/page.php?lang=1\&page=1655\&page_id=794

Dobrovolsky S., Kubarev V. 2009. Mutagenesis and recombinogenesis of agricultural plants. Journal the World of Science 7(77).

Dospekhov B.A. 1973. Field experiment methodology. Moscow “Kolos”,pp. 335.

Gerard J., Harriet H., Benbowb R., Singh D., Ewen R. 2020. Improvements in Genomic Technologies: Applications to Crop Research. Reference Module in Food Science. https://doi.org/10.1016/B978-0-08-100596-5.22693-0

Hu Y., Han Y., Zhang Y. 2020. Land desertification and its influencing factors in Kazakhstan. Journal of Arid Environments180:104-203.https://doi.org/10.1016/j.jaridenv.2020.104203

IAEA 2019. Plant Breeding and Genetic Newsletter. Joint FAO/IAEA Programme. Nuclear techniques in Food and Agriculture no.43.http://www.fao.org/ag/portal/index_en.html 
Jo Y.D., Kim J-B. 2019. Frequency and spectrum of radiation-induced mutations revealed by wholegenome sequencing analyses of plants. Quantum Beam Science 3(7):2-13, doi10.3390/qubs3020007.

Kazakova E.A., Makarenko E.S., Podlutsky M.S. et al 2020. Radio Sensitivity of the winter and spring barley varieties according to the morphological effect of low-dose gamma irradiation on the original seeds. Grain Economy of Russia 2(68):23-28. DOI:10.31367/2079-8725-2020-682-23-28 (in Russian).

Kim J.S., Kim J.K., Lee Y.K., Baek M.W., Kim J.G. 1998. Effects of low dose gamma radiation on the germination and yieldcomponents of Chinese cabbage. Kor. J. Environ. Agr. 17: 274-278.

Korystov Y.N., Narimanov A.A. 1997. Low doses of ionizing radiation and hydrogen peroxidase stimulate plant growth.Biologia (Bratisl.)52:121-124.

Kumari R., Singh Y. 1996. Effect of gamma-rays and EMS onseed germination and plant survival of Pisum sativumL., and Lens culinaris. Medic. Neo Botanica 4(1):25-29.

Kuzin A.M., Vagabova M.E., Prinak-Mirolyubov V.N. 1975. Molecular mechanisms of the stimulating effect of ionizing radiation on seed. Activation of RNA synthesis. Radiobiol.15:747-750.

LiuS.,JiangJ.,LiuY.,MengJ.,XuSh. 2019. Characterization and Evaluation of OsLCT1 and OsNramp5 Mutants Generated Through CRISPR/Cas9-Mediated Mutagenesis for Breeding Low Cd Rice. Rice Science 26(2):88-97.https://doi.org/10.1016/j.rsci.2019.01.002

Majeed A, Muhammad Z. 2010. Gamma irradiation effects on some growth parameters of Lepidium sativum L. World J Fungal Plant Biol. 1(1):39-42.

Marcu D., Cristea V., Darban L. 2013. Dose-dependent effects of gamma radiation on lettuce (Lactucasativa var. capitata) seedlings. Int J Radiat Biol. 89:219-223.

Mattson M. P., Calabrese E. J. 2010. Hormesis: A revolution in biology, toxicology and medicine. Humana Press Inc., 213 p.

Melki M., Dahmani T.H. 2009. Gamma irradiation effects ondurum wheat (Triticum durumDesf) under various conditions.Pak. J. Biol. Sci. 12(23):1531-1534. doi:10.3923/pjbs.2009.1531.1534.

Methodological guidelines. 1981. Methodological Guidelines for Studying the World Barley Collection. Plant Breeding Research Institute (VIR), Leningrad, pp. 30.

Methodological guidelines. 1989. Analysis of plants by growth rates at the initial stages of ontogenesis. Leningrad, Plant Breeding Research Institute (VIR) (Анализ растений по ростовым показателям на начальных этапах онтогенеза: Методические указания, Ленинград, ВИР), pp. 18.

Naito K., Kusaba M., Shikazono N, Takano T, Tanaka A, Tanisaka T, Nishimura M. 2005. Transmissible and nontransmissible mutations induced by irradiating Arabidopsis thaliana pollen with $\lambda$-rays and carbon ions. Genetics, 169:881-889. 
Preuss S.B., Britt A.B. 2003. A DNA-damage-induced cellcycle checkpoint in Arabidopsis.Genetics, 64:323-334

Rawat V.S., Singh S.S., Wani M.R., et al. 2019. Potential of fractionated doses of gamma rays to stimulate growth and yield of Amaranthuscaudatus in M1 (First filial generation) and M2 (Second filial generation) generation. Forest Res EngInt J., 3(3):76-81. DOI: 10.15406/freij.2019.03.00081

Reynolds J. F., Smith D.M.S., Lambin E.F., Turner B.L., Mortimore M., Batterbury S.P.J., Downing T., Dowlatabadi, Fernández R.J. et al. 2007. Global Desertification: Building a Science for Dryland Development. Science 316(5826): 847-851 https://doi.org/ 10.1126/science.1131634

ShiyuW.,YihaoY.,MinG.,ChongyuanZh. 2020. Targeted mutagenesis of amino acid transporter genes for rice quality improvement using the CRISPR/Cas9 system. The Crop Journal, 8(3):457-464 https://doi.org/10.1016/j.cj.2020.02.005

Thapa C.B. 2004. Effect of acute exposure of gamma rays on seedgermination and seedling growth of Pinus kesiyagord and P. Wallichiana A.B. Jacks. Our Nature. 2(1):13-17 doi:10.3126/on.v2i1.318.

Thomas J. 2020. Chapter 8 - Enhancement of Germplasm. Horticultural Plant Breeding, pp. 129-148. https://doi.org/10.1016/B978-0-12-815396-3.00008-1

Udovenko G.V. 1968. Diagnostics of plant resistance to stress. Methodical guidance (Диагностика устойчивости растений к стрессовым воздействиям. Методическое руководство)Leningrad, pp. 19.

Verón S.R.,Paruelo J.M., Oesterheld M. 2006. Assessing desertification. Journal of Arid Environments, Vol. 66, Issue 4, Pages 751-763. https://doi.org/10.1016/j.jaridenv.2006.01.021

VolkovaP.Yu., Duarte G.T., Soubigou-Taconnat L., Kazakova E.A. et al 2020. Early response of barley embryos to low- and high-dose gamma irradiation of seeds triggers changes in the transcriptional profile and an increase in hydrogen peroxide content in seedlings. J Agronomy and Crop Science. 206(2): 277-295. https://doi.org/10.1111/jac.12381

Wang B., Zhong Zh., Zhang H., Wang X., Liu B.,YangL.,HanX.,YuD.,ZhengX. 2019. Targeted Mutagenesis of NAC Transcription Factor Gene, OsNAC041, Leading to Salt Sensitivity in Rice. Rice Science, 26(2):98-108.https://doi.org/10.1016/j.rsci.2018.12.005

Wang X., Ma R., Cui D., Cao Q., Shan Z., Jiao Z. 2017. Physio-biochemical and molecular mechanism underlying the enhanced heavy metal tolerance in highland barley seedlings pretreated with low-dose gamma irradiation. Sci Rep. 27, 7(1):14233. doi: 10.1038/s41598-01714601-8.

Wi S.G., Chung B.Y., Kim J.H., Baek M.H., Yang D.H., Lee J.-W., Kim J.-S. 2005. Ultrastructural changes of cell organelles in Arabidopsis stem after gamma irradiation. J. Plant Biol., 48(2):195-200. doi:10.1007/BF03030408. 
Yu X., Wu H., Wei L.J., Cheng Z., Xin P., Huang C., Zhang K., Sun Y.Q. 2007. Characteristics of phenotype and genetic mutations in rice after spaceflight. Adv. Space Res., 40(4):528-534. doi:10.1016/j.asr.2007.06.022.

Zimmermann M.W., Gartenbach K.E., Kranz A.R., Baican B.,Schopper E., Heilmann C., Reitz G. 1996. Recent results of comparative radiobiological experiments with short and long term expositions of Arabidopsis seed embryos. Adv. Space Res., 18(12):205-213. doi:10.1016/02731177(96)00041-5. 


\section{Ефекти јонизујућег зрачења семена на почетни пораст јечма, одређивање учесталости и спектра мутационе променљивости у морфолошким својствима $\mathrm{M}_{1}$}

Laura Tokhetova, Bibigul Baizhanova*, Raushan Nurymova, Danabek Nurzhanov, Nurali Nurgaliev

Korkyt Ata Kyzyl-Orda State University, 120014, Kyzylorda, Aitekebie str. 29A, Republic of Kazakhstan

*Corresponding author: bibi64@inbox.ru

\section{Извод}

Сматра се да је технологија гама зрачења врло обећавајућа за модификацију неких особина биљака. Ефекат гама-зрачења на клијавост, раст и продуктивност мутираног потомства јечма је изузетно значајан. Циљеви студије били су стварање новог изворног материјала за оплемењивање јечма у облику мутираних линија са пожељним особинама, третирањем семена јонизујућим зрачењем помоћу електронског акцелератора (Парк нуклеарних технологија JSC, Курчатов, Република Казахстан); као и да побољшање и проширење класичних метода оплемењивања заснованих на индукованој мутагенези, у стварању оригиналног генофонда материјала јечма за убрзано и ефикасно увођење сорти толерантних на стрес (заслањеност и сушу) у производним условима предела Аралског мора. Семе две сорте јечма третирано је са пет доза зрачења (од 50 до $250 \mathrm{~Gy}$ ). Клијавост и поједине морфолошке карактеристике младих биљака у различитим фазама раста упоређене су са незраченим (контролним) третманом. Резултати овог прелиминарног истраживања показали су да су биљке чије је семе третирано гама-зрачењем реаговале на све дозе зрачења и да су испољиле потиснута морфолошка својства. Добијени резултати могу се применити као основа за даља истраживања и са другим дозама гама-зрачења семена биљака, како би се створила основа за јачање и примену целокупног оплемењивачког рада, за диверзификовану биљне производње у региону и побољшање карактеристика постојећег сортимента.

Кључне речи: гама-зрачење, селекција, јечам, мутантне линије. 